\title{
The Change of Some Food Elements in Soil Depending On Shadowing and Fertilization
}

\author{
İnci Sevinç Kravkaz Kuşçu ${ }^{1, a, *}$, Sayed Moqadas Sharaf ${ }^{2, b}$ \\ ${ }^{1}$ Faculty of Forestry, Kastamonu University, 37210 Kastamonu, Turkey \\ ${ }^{2}$ Graduate School of Natural and Applied Sciences, Kastamonu University, 37210 Kastamonu, Turkey
}

*Corresponding author

\begin{tabular}{l|l}
\hline A R T I C L E I N F O & A B S T R A C T \\
\hline $\begin{array}{l}\text { Research Article } \\
\text { Received : 27/01/2021 }\end{array}$ & $\begin{array}{l}\text { Soil is one of the most important factors affecting the plant development on the basis. The method } \\
\text { mostly applied for the purpose of accelerating the plant development and ensuring the increase in } \\
\text { products is to increase the nutrients in the soil, namely fertilization. Fertilization ensures lots of food } \\
\text { elements in the soil to get mixed in the soil and change the soil composition. Another factor affecting } \\
\text { the plant growth speed and productivity is shadowing. Shadow conditions change the light receiving } \\
\text { amounts of the plant and directly affect the plant photosynthesis speed. In addition; shadowing not } \\
\text { only affects the dissolution and in-soil mixture speed of the fertilizers applied to the soil, but it also } \\
\text { directly affects the humidity content of the soil. In this study, it has been aimed to determine the } \\
\text { food element changes in the soil on the lavender individuals grown under different shadow } \\
\text { conditions and fertilized with different fertilizers. The lavender used in the study has been selected } \\
\text { due to the fact that it adapts to dry areas, it is abstinent in terms of soil and it is an important and } \\
\text { income-generating medical aromatic plant. As a result of the study, it has been determined that } \\
\text { shadowing statistically affects salt, carbon, phosphor, nitrogen and potassium and fertilization } \\
\text { statistically affects phosphor, nitrogen, potassium, carbon and salt at least at 95\% confidence level. }\end{array}$ \\
$\begin{array}{l}\text { Keywords: } \\
\text { Soil } \\
\text { Shadowing } \\
\text { Fertilization } \\
\text { Food Substances } \\
\text { Lavender }\end{array}$ &
\end{tabular}

\section{Introduction}

Plants are the most important living being groups in the world and all the life in the world is directly or indirectly dependent on plants (Aricak et.al., 2020; Yigit et.al., 2018). Plant development is shaped depending on the climatic and edaphic conditions of the environment plants are grown (Turkyilmaz et.al., 2020; Cetin et.al., 2020). Under these conditions, soil is one of the most important factors affecting the development of the plant on the basis and the food substances in the soil play a vital role in plant development. The development and growth of the plant stop or the plant dies in the deficiency of the substances providing food to the soil. In such situations, it is necessary to add food substances to the soil and this is ensured by fertilization. Fertilization ensures many food elements in the soil to rapidly get mixed in the soil and change the soil composition (Sharaf, 2020).

A good development of the plant in the soil is related to the physical and chemical characteristics of the soil environment it grows. The method mostly applied in rehabilitating the physical characteristics of the soil and ensuring its sustainability is to add organic based materials to the soil, namely fertilization. The conducted studies show that in the event that there are sufficient dissolved organic substance wastes in the mineral soil, it has significant impact on the physical and chemical characteristics of the mineral structure of the soil (Özgövercikli, 2020). The determination of the physical and chemical characteristics of the soil structure is vitally significant in planning the vegetative production and conducting the regulations that will ensure increase in products (Kravkaz Kuşcu et.al., 2017; Melek, 2020).

It is important to take the biological issues into consideration in the evaluation of the functions related to fertility and soil protection in complex soil system. In this study, it has also been tried to determine the impact of different shadow and fertilizer conditions on soil characters. 


\section{Material and Method}

\section{Experimental Design}

In the study, it has been tried to determine how different fertilization applications affect the food substance in the soil under different shadow conditions. Within the scope of the study, firstly pots have been prepared and the lavender saplings have been placed in the study area. Shadowy environments have been primarily prepared. For this purpose, greenhouse frames have been formed in a way that they will be $2 \mathrm{~m}$ high from the ground, four different parcels have been formed in this area and the upper surfaces of these parcels have been covered with; a) $35 \%$ shade, b) $55 \%$ shade, c) $75 \%$ shade and d) $95 \%$ shade and the plants have been placed in the parcels in a way that light gliding from the related shade will reach the plants in the parcels from the sunrise to the sunset. In this way, the plants have been exposed to shadow in the same ratio during the day. $5^{\text {th }}$ group plant has been left to outdoor conditions and in this way, environments with $100 \%$ sunlight, $65 \%$ sunlight, $45 \%$ sunlight, $25 \%$ sunlight and $5 \%$ sunlight have been prepared.

In the next stage of the study, the used lavender saplings have been supplied and placed in the study area, namely below the shades. 40 ea. potted saplings have been placed in each shade and in this way, 200 ea. saplings have been used in total. Fertilization applications were conducted right before the commencement of vegetation in early March. Three different fertilizers have been used as the fertilization application. The fertilizers are; a) Cattle manure (Cow), b) Small cattle manure (Sheep) and c) Poultry manure.

Fertilization has not been conducted in one group and it has been used as control group. Each fertilization application has been applied to 10 ea. saplings in each shade. In this way, application has been conducted in 5 shades $\times 4$ fertilizers $\times 10$ saplings $=200$ ea. saplings in a way that there will be 10 saplings in each shade and each fertilization. Analyses have been conducted by uprooting the plants and taking soil samples at the end of the vegetation season. Fertilizer amounts have been determined depending on the pot magnitudes after the experiment has been established.

\section{Food Element Analyses}

The Determination of Micro Food Elements; the Fe, $\mathrm{Zn}, \mathrm{Cu}$ and $\mathrm{Mn}$ concentrations have been determined in Perkin Elmer Optima 2100 DV model ICP-OES (Inductively Coupled Plasma-Optical Emission) device in the filter extracted by shaking up with $0.005 \mathrm{M}$ DTPA (diethylene triamine penta acetic acid) $+0.01 \mathrm{M} \mathrm{CaCl} 2+$
0.1 M TEA (triethanolamine) mixture solution $(\mathrm{pH}=7.3)$ for two hours in a way that the soil-solution ratio will be $1: 2$.

The Determination of Macro Food Elements; the total nitrogen amount of the soil as specified by Bremner (1965) according to Kjeldahl method and phosphor as specified by Olsen et.al., (1954); the phosphor amount (P) getting through the solution by extracting with $0.5 \mathrm{~N} \mathrm{NaHCO}_{3}$ (pH: 8.5) has been determined in Perkin Elmer Optima 2100 DV model ICP-OES (Inductively Coupled PlasmaOptical Emission) device.

The changeable potassium $(\mathrm{K})$ as specified by Pratt (1965); the soil samples have been extracted with 1,0 N neutral ( $\mathrm{pH}$ : 7.0) ammonium acetate $\left(\mathrm{CH}_{3} \mathrm{COONH}_{4}\right)$ and the potassium in the filter $(\mathrm{K})$ has been determined in Perkin Elmer Optima 2100 DV model ICP-OES (Inductively Coupled Plasma-Optical Emission) device.

\section{Result and Discussion}

\section{The Impact of Shadowing on Soil Characters}

Within the scope of the study, the data attained by determining the salt, $\mathrm{pH}$, lime $\left(\mathrm{CaCO}_{3}\right)$, phosphor $(\mathrm{P})$, potassium $(\mathrm{K})$, carbon $(\mathrm{C})$, nitrogen $(\mathrm{N})$ and organic substance (OS) amounts of the soil have been subjected to variance analysis and the results are shown in Table 1.

According to the results of Duncan test; it has been determined that the change of $\mathrm{pH}$, lime, $\mathrm{K}$ and $\mathrm{OM}$ amounts depending on shadowing are not at a statistically significant level $(\mathrm{P}>0.05)$. As a result of Duncan analysis, salt amount has accumulated in two homogeneous groups. While 5\% light forms the first homogeneous group, the values attained in other light amounts have formed the second homogeneous group.

Two homogeneous groups have occurred also in terms of $\mathrm{P}$ amount and while $25 \%$ and $65 \%$ lights form the first homogeneous group, the values attained from other light amounts have formed the second homogeneous group. Two groups have occurred also in terms of nitrogen and the lowest values have been attained the areas with $5 \%$ and $25 \%$ lights. In terms of C, $25 \%$ light areas have taken place in the first group and all other light amounts have taken place in the second group.

\section{The Impact of Fertilization on Soil Characters}

Within the scope of the study; sheep manure, poultry manure, cow manure and manure-free control group have occurred. The impact of fertilization on the characters evaluated within the scope of the study are given in Table 2 .

Table 1. The Impact of Shadowing on Soil Characters

\begin{tabular}{l|llllllll}
\hline Light $(\%)$ & \multicolumn{1}{c}{$\mathrm{EC}\left(\mu \mathrm{S} . \mathrm{cm}^{-1}\right)$} & $\mathrm{pH}$ & $\mathrm{CaCO}_{3}(\%)$ & $\mathrm{P}(\mathrm{ppm})$ & $\mathrm{K}(\mathrm{ppm})$ & $\mathrm{N}(\%)$ & $\mathrm{C}(\mathrm{ppm})$ & $\mathrm{OM}(\%)$ \\
\hline 5 & $0.425^{\mathrm{b}}$ & 7.679 & 0.388 & $30.841^{\mathrm{a}}$ & 109.263 & $1.097^{\mathrm{ab}}$ & $16.979^{\mathrm{b}}$ & $7.814^{\mathrm{ab}}$ \\
25 & $0.312^{\mathrm{a}}$ & 7.631 & 0.388 & $50.211^{\mathrm{b}}$ & 171.994 & $0.951^{\mathrm{a}}$ & $13.441^{\mathrm{a}}$ & $6.653^{\mathrm{a}}$ \\
45 & $0.2988^{\mathrm{a}}$ & 7.661 & 0.388 & $37.857^{\mathrm{a}}$ & 101.676 & $1.187^{\mathrm{b}}$ & $18.169^{\mathrm{b}}$ & $6.649^{\mathrm{a}}$ \\
65 & $0.3525^{\mathrm{a}}$ & 7.664 & 0.388 & $50.970^{\mathrm{b}}$ & 148.537 & $1.224^{\mathrm{b}}$ & $18.680^{\mathrm{b}}$ & $8.529^{\mathrm{ab}}$ \\
100 & $0.3081^{\mathrm{a}}$ & 7.705 & 0.388 & $25.873^{\mathrm{a}}$ & 120.283 & $1.194^{\mathrm{b}}$ & $19.009^{\mathrm{b}}$ & $8.819^{\mathrm{b}}$ \\
$\mathrm{F}$ & $7.034^{* * *}$ & $0.014^{\text {ns }}$ & $0.000^{\text {ns }}$ & $4.977^{* *}$ & $2.715^{\text {ns }}$ & $2.865^{*}$ & $5.950^{* * *}$ & $2.107^{\mathrm{ns}}$ \\
\hline
\end{tabular}


Table 2. The Impact of Fertilization on Soil Characters

\begin{tabular}{|c|c|c|c|c|c|}
\hline \multirow{2}{*}{ Soil Characters } & \multicolumn{4}{|c|}{ Fertilizers } & \multirow{2}{*}{ F Value } \\
\hline & Sheep & Chicken & Cow & Control & \\
\hline $\operatorname{EC}\left(\mu \mathrm{S}_{\mathrm{c}} \mathrm{cm}^{-1}\right)$ & $0.363^{\mathrm{b}}$ & $0.372^{\mathrm{b}}$ & $0.300^{\mathrm{a}}$ & $0.321^{\mathrm{a}}$ & $3.186^{*}$ \\
\hline $\mathrm{pH}$ & 7.643 & 7.618 & 7.719 & 7.692 & $0.052 \mathrm{~ns}$ \\
\hline $\mathrm{CaCO}_{3}(\%)$ & 0.388 & 0.388 & 0.388 & 0.388 & $0.000 \mathrm{~ns}$ \\
\hline $\mathrm{P}(\mathrm{ppm})$ & $48.927^{\mathrm{b}}$ & $53.939^{\mathrm{b}}$ & $23.225^{\mathrm{a}}$ & $30.510^{\mathrm{a}}$ & $12.531^{* * * *}$ \\
\hline $\mathrm{K}(\mathrm{ppm})$ & $169.956^{\mathrm{b}}$ & $185.748^{\mathrm{b}}$ & $84.933^{\mathrm{a}}$ & $80.764^{\mathrm{b}}$ & $18.476^{* *}$ \\
\hline $\mathrm{N}(\%)$ & $1.180^{\mathrm{b}}$ & $1.209^{\mathrm{b}}$ & $0.899^{\mathrm{a}}$ & $1.234^{\mathrm{b}}$ & $8.227^{* * *}$ \\
\hline $\mathrm{C}(\mathrm{ppm})$ & $17.757^{\mathrm{b}}$ & $18.459^{\mathrm{b}}$ & $14.145^{\mathrm{b}}$ & $18.659^{\mathrm{a}}$ & $6.150^{* *}$ \\
\hline $\mathrm{OM}(\%)$ & 8.739 & 8.270 & 6.650 & 7.113 & $2.614^{\mathrm{ns}}$ \\
\hline
\end{tabular}

Table 3. Results of Correlation Analysis

\begin{tabular}{|c|c|c|c|c|c|}
\hline \multirow{2}{*}{ Soll Characters } & \multicolumn{4}{|c|}{ Fertilizers } & \multirow{2}{*}{$\mathrm{F}$} \\
\hline & Sheep & Chicken & Cow & Control & \\
\hline $\mathrm{EC}\left(\mu \mathrm{S} . \mathrm{cm}^{-1}\right)$ & $0.363^{b}$ & $0.372^{\mathrm{b}}$ & $0.300^{\mathrm{a}}$ & $0.321^{\mathrm{a}}$ & $3.186^{*}$ \\
\hline $\mathrm{pH}$ & 7.643 & 7.618 & 7.719 & 7.692 & $0.052^{\mathrm{ns}}$ \\
\hline $\mathrm{CaCO}_{3}(\%)$ & 0.388 & 0.388 & 0.388 & 0.388 & $0.000 \mathrm{~ns}$ \\
\hline $\mathrm{P}(\mathrm{ppm})$ & $48.927^{\mathrm{b}}$ & $53.939^{\mathrm{b}}$ & $23.225^{\mathrm{a}}$ & $30.510^{\mathrm{a}}$ & $12.531^{* * * *}$ \\
\hline $\mathrm{K}(\mathrm{ppm})$ & $169.956^{\mathrm{b}}$ & $185.748^{b}$ & $84.933^{\mathrm{a}}$ & $80.764^{\mathrm{b}}$ & $18.476^{* *}$ \\
\hline $\mathrm{N}(\%)$ & $1.180^{\mathrm{b}}$ & $1.209^{\mathrm{b}}$ & $0.899^{\mathrm{a}}$ & $1.234^{\mathrm{b}}$ & $8.227^{* * *}$ \\
\hline $\mathrm{C}(\mathrm{ppm})$ & $17.757^{\mathrm{b}}$ & $18.459^{\mathrm{b}}$ & $14.145^{\mathrm{b}}$ & $18.659^{\mathrm{a}}$ & $6.150^{* * *}$ \\
\hline $\mathrm{OM}(\%)$ & 8.739 & 8.270 & 6.650 & 7.113 & $2.614^{\mathrm{ns}}$ \\
\hline
\end{tabular}

As a result of the variance analysis; the impact of shadowing on $\mathrm{pH}$, lime and $\mathrm{OS}$ has been found at a statistically insignificant level $(\mathrm{P}<0.05)$. As a result of Duncan test; it is seen that control and cow manure in terms of salt and $\mathrm{P}$, cow manure in terms of $\mathrm{K}$ and $\mathrm{N}$ and control group has formed the first homogeneous groups in terms of $\mathrm{C}$ and other fertilizations have formed the second groups. The results of the correlation analysis showing the relation levels of the soil characters subjecting to the study to one another are given in Table 3.

As a result of the study; it has been determined that most of the characters subjecting to the study are in a strong relation to one another at a statistically significant level. It has also been determined that lime and $\mathrm{pH}$ being from the characters subjecting to the study are just in relation to each other, the relation between salt and organic substance is at a statistically significant level and their relations to the characters except for these ones are at a statistically insignificant level. Other characters are at a statistically significant relation to one another. All the relations among these characters are related to one another in positive direction.

According to the results of correlation analysis; it has been determined that the strongest relations are between $\mathrm{pH}$ and lime (0.996), nitrogen and carbon (0.968) and phosphor and potassium (0.802). Besides; the relation between organic substance and salt $(0.763)$ and potassium (0.654) is also very strong.

As a result of the conducted study; the impact of shadowing and fertilization on many characters has been found at a statistically significant level (at least $\mathrm{P}<0.05$ ). As a result of the study, it is seen that salt amount is at a high level in 5\% shadowing in the shadowing applications. The reason for this situation is thought to be due to the fact that the plants cannot benefit from the sunlight sufficiently and therefore, photosynthesis is made less and there is no loss of salt (Sharaf, 2020). Salt is one of the most important problems in agricultural soils and high amount of salt is an undesired situation (Melek, 2020).

Plant development is actually shaped under the impact of the genetic structure of the plant (Hrivnak et al., 2017) and the environmental conditions (Sevik et al., 2019a,b; Turkyilmaz et al., 2019; Mutlu and Güzel, 2019; Emin et al., 2020). One of the most important environmental conditions affecting the plant development is light (Kapucu et al., 2016; Cetin et al., 2018a,b). Light is the main component of photosynthesis and therefore, it shapes the development, form and morphological and anatomical characters of the plants (Yigit et al., 2019).

Light is accepted as the most important factor affecting the growth by most researchers. It has been revealed by the conducted studies that light is the most important factor affecting the diameter growth (Mäkinen et al., 2003) and the crown structure (Hein et al., 2007). The morphological characters such as petiole length, space between nodes and total stolon number are directly related to the spectral light quality (Sevik et al., 2017). In addition; the survival of the plants in the areas such as forest subgrade where light is limited is also dependent on light. Moreover; the sequences of the branches in a way that they will not block one another and ensure the light to reach the lower layers have a critical importance for the light receiving and survival of the intermediate and lower layers (Valladares and Niinemets, 2007; Kapucu, 2016; Ertugrul et al., 2021). There are many studies revealing that light amount affects the micro-morphological characters (Aydemir Özcan, 2017; Yiğit et al., 2018; Sevik et al., 2019c), stomatal characters (Sevik et al., 2017), chlorophyll amount (Cetin, 2016) leaf structure (Kacar et al., 2010) and growth performance (Sharaf, 2020).

In the study, statistical examination has been conducted in terms of the impact of fertilization on the characters and according to the results of the variance analysis, it has been determined that it statistically significantly $(\mathrm{P}<0.05)$ 
affects the ratios of $\mathrm{P}, \mathrm{K}, \mathrm{N}$ and $\mathrm{C}$. In all these character; as a result of Duncan test, sheep and poultry manures have been determined to be in the second homogeneous group.

Organic substance is vitally important for soil productivity and the most efficient food elements are $\mathrm{N}, \mathrm{P}$ and $\mathrm{K}$ in the production of agricultural products. The amount of these food elements in the soil constantly decreases depending on the growth environment and production. Most of the agricultural soils in our country are insufficient in terms of organic substance and the mineral and organic fertilizers are the most important solutions to terminate the deficiency of soil food elements (Melek, 2020). For this reason; many studies have been conducted in the issue of the impact of different fertilizers on the development of different plant species (Sharaf, 2020).

The morphological and physiological characters in plants are shaped with the interaction of genetic structure and environmental factors (Yigit et al., 2016a,b; Sevik et al., 2020a,b). Thereof; there are many factors related to one another and affecting the development of the plants (Turkyilmaz et al., 2018a,b; Aricak et al., 2019). Many factors such as precipitation, temperature, stress factors, light, air pollution and soil structure as well as genetic structure affect the plant development and therefore, agricultural product amount (Sevik et al., 2020c,d; Yucedag et al., 2019).

Light and soil characters are the main factors among the most efficient ones (Kravkaz Kuşcu et al., 2018a,b; Ozel et al., 2020). Thereof; many studies are conducted in the issue of the impacts of these factors for the purpose of being able to receive more products per unit area. However; it is also necessary to separately determine the relations of these factors with one another.

\section{References}

Aricak B, Cetin M, Erdem R, Sevik H, Cometen H. 2019. The Change of Some Heavy Metal Concentrations in Scotch pine (Pinus sylvestris) Depending on Traffic Density, Organelle and Washing. Applied Ecology and Environmental Research, 17 .3. pp. 6723-6734. Doi:http://dx.doi.org/10.15666/aeer/ 1703_67236734.

Aricak B, Cetin M, Erdem R, Sevik H, Cometen H. 2020. The Usability of Scotch Pine (Pinus sylvestris) as a Biomonitor for Traffic-Originated Heavy Metal Concentrations in Turkey. Polish Journal of Environmental Studies, 29.2. pp.1051-1057. Doi: https://doi.org./10.15244/pjoes/109244.

Aydemir Özcan AG. 2017. The Effects of Shading and Fertilising Applications on Flower Yield and Growth in Lavender (Lavandula angustifolia Miller.). MsC Thesis Graduate School of Natural and Applied Sciences Department of Sustainable Agriculture and Natural Plant Resources, Kastamonu University, Kastamonu, Turkey.

Bremner JM. 1965. Total nitrogen. Methods of soil analysis. Part 2. Chemical and microbiological properties. Ed. C.A. Black. Amer. Soc. of Agron. Inc. Pub. Agron. Series. No: 9, pp: 1149-1178. Madison, Wisconsin, U.S.A.

Cetin M. 2016. Changes in the amount of chlorophyll in some plants of landscape studies. Kastamonu Üniversitesi Orman Fakültesi Dergisi, 16 .1. Pp. 239-245.

Cetin M, Sevik H, Yigit N. 2018a. Climate Type-Related Changes in The Leaf Micromorphological Characters of Certain Landscape Plants. Environmental monitoring and assessment, $190 \quad$.7. 404. pp.1-9. Doi:https://doi.org/ $10.10007 / \mathrm{s} 10661-018-6783-3$
Cetin M, Sevik H, Yigit N, Ozel HB, Aricak B, Varol T. 2018b. The Variable of Leaf Micromorphogical Characters on Grown in Distinct Climate Conditions in Some Landscape Plants. Fresenius Environmental Bulletin, 27. 5. pp. 3206-3211.

Cetin M, Sevik H, Cobanoglu O. 2020. Ca, Cu, and Li in Washed and Unwashed Specimens of Needles, Bark, and Branches of The Blue Spruce (Picea pungens) in the City of Ankara. Environmental Science and Pollution Research, pp. 2181621825. Doi: https://doi.org/10.1007/s11356-020-08687-3.

Ertugrul M, Varol T, Ozel HB, Cetin M, Sevik H. 2021. Influence of climatic factor of changes in forest fire danger and fire season length in Turkey. Environmental Monitoring and Assessment, 193.1.pp.1-17. Doi:https://doi.org

Heın S, Mäkınen H, Yue C, Kohnle U. 2007. Modelling Branch Characteristics of Norway Spruce from Wide Spacings in Germany. Forest Ecology Management, 242. 2. 155.pp. Doi: https://doi.org10.1016/foreco.2007.01.014.

Hrivnák M, Paule L, Krajmerová D, Kulaç Ş, Şevik H, Turna İ, Tvauri I, Gömöry D. 2017. Genetic variation in Tertiary relics: The case of eastern-Mediterranean Abies (Pinaceae). Ecology and evolution, 7: 23. pp.10018-10030.

Kacar B, Katkat V, Öztürk Ş. 2010. Bitki Fizyolojisi (4. Bask1). Ankara: Nobel Yayın Dağıtım.

Kapucu Ö. 2016. The Effect of Light on The Sapling Forms of Turkish Fir (Abies nordmanniana subsp. bornmulleriana Mattf.). MSc. Thesis. Graduate School of Natural and Applied Sciences Department of Forest Engineering, Kastamonu University, Kastamonu, Turkey.

Kravkaz Kuşcu İS, Karaöz ÖM, Şevik H, Yiğit N. 2017. Üreaz Enzim Aktivitesi. Uluslararası Taşköprü Pompeiopolis Bilim Kültür Sanat Araştırmaları Sempozyumu, 10-12 Nisan 2017, Kastamonu. pp.1525-1531.

Kravkaz Kuscu IS, Cetin M, Yigit N, Savaci G, Sevik H. 2018a. Relationship between Enzyme Activity (Urease-Catalase) and Nutrient Element in Soil Use. Polish Journal of Environmental Studies, 27. 5. pp. 2107-2112. Doi: 10.15244/pjoes/78475.

Kravkaz-Kuscu IS, Sariyildiz T, Cetin M, Yigit N, Sevik H, Savaci G. 2018b. Evaluation of the soil properties and primary forest tree species in Taskopru (Kastamonu) district. Fresenius Environmental Bulletin, 27. 3. pp. 1613-1617.

Mäkınen H, Ojansuu R, Saoranen P, Yl1-Kojola H. 2003. Predicting Branch Characteristics of Norway Spruce (Picea abies (L.) Karst.) from Simple Stand and Tree Measurements. Forestry, 76. 5. 525.

Melek T. 2020. Evaluation of Some Soil Characteristics in Devrekani Agricultural Soil With The Help of Geographical Information Systems. MsC Thesis. Graduate School of Natural and Applied Sciences Department of Sustainable Agriculture and Natural Plant Resources, Kastamonu University, Kastamonu, Turkey.

Olsen SR, Cole CV, Watanabe FS, Dean NC. 1954. Estimation of available phosphous in soil by extraction with sodium bicorbonate. U. S. Dept of Agr. Cir. 939, Washington. D.C.

Özgövercikli F. 2020. Investigation of Soil Efficiency in Agricultural Areas of Kastamonu Province Devrekani District, MsC Thesis. Graduate School of Natural and Applied Sciences Department of Sustainable Agriculture and Natural Plant Resources, Kastamonu University, Kastamonu, Turkey.

Ozel HB, Donduran B, Cakmakli E, Sevik H. 2020. Factors Affecting Success in Natural Regeneration Works of Cedar (Cedrus libani A. Rich.) In Kas Region of Antalya. World Journal of Advanced Research and Reviews, 6. 2. pp. 054059. Doi: 10.30574/wjarr.2020.6.2.0127.

Sevik H, Cetin M, Kapucu O, Aricak B, Canturk U. 2017. Effects of light on morphologic and stomatal characteristics of Turkish Fir needles (Abies nordmanniana subsp. Bornmulleriana Mattf.). Fresenius Environmental Bulletin, 26.11. pp.6579-6587. 
Sharaf SM. 2019. Following Change and Fertilization of Some Nutrient Elements in Soil, MsC Thesis. Graduate School of Natural and Applied Sciences Department of Sustainable Agriculture and Natural Plant Resources, Kastamonu University, Kastamonu, Turkey.

Sevik H, Cetin M, Ozel HB, Akarsu Cetin IZ. 2020c. Analyzing of Usability of Tree-rings as Biomonitors for Monitoring Heavy Metal Accumulation in the Atmosphere in Urban Area: a Case Study of Cedar Tree (Cedrus sp.) Environmental Monitoring and Assessment, 192. 1. 23. Doi: 10.1007/s10661-019-8010-2

Sevik H, Cetin M, Ozel HB, Erbek A, Cetin IZ. 2020b. The Effect of Climate on Leaf Micromorphological Characteristics İn Some Broad-Leaved Species. Environment, Development and Sustainability, pp.1-13. Doi: https://doi.org/10.1007/ s10668-020-00877-w

Sevik H, Cetin M, Ozel HU, Ozel HB, Mossi MMM, Cetin IZ. 2020a. Determination of $\mathrm{Pb}$ and $\mathrm{Mg}$ Accumulation in Some of The Landscape Plants in Shrub Forms. Environmental Science and Pollution Research, 27. 2. pp. 2423-2431.

Sevik H, Cetin M, Ozturk A, Ozel HB, Pinar B. 2019a. Changes in $\mathrm{Pb}, \mathrm{Cr}$ and $\mathrm{Cu}$ Concentrations in Some Bioindicators Depending on Traffic Density on The Basis of Species and Organs. Applied Ecology and Environmental Research, 17. 6. pp. 12843-12857.

Sevik H, Ozel HB, Cetin M, Özel HU, Erdem T. $2019 \mathrm{~b}$. Determination of Changes in Heavy Metal Accumulation Depending on Plant Species, Plant Organism, and Traffic Density in Some Landscape Plants. Air Quality, Atmosphere \& Health, 12. 2. pp. 189-195.

Sevik H, Cetin M, Ozturk A, Yigit N, Karakus O. 2019c. Changes in micromorphological characters of Platanus orientalis L. leaves in Turkey. Applied Ecology and Environmental Research, 17. 3. pp. 5909-5921.

Sevik H, Cetin M, Ozel HB, Erbek A, Cetin IZ. 2020d. The effect of climate on leaf micromorphological characteristics in some broad-leaved species. Environment, Development and Sustainability, pp. 1-13.

Turkyilmaz A, Cetin M, Sevik H, Isinkaralar K, Saleh EAA. 2020. Variation of Heavy Metal Accumulation in Certain Landscaping Plants Due to Traffic Density. Environment, Development and Sustainability, 22. 3. pp. 2385-2398.
Turkyilmaz A, Sevik H, Cetin M, Ahmaida Saleh EA. 2018a. Changes in Heavy Metal Accumulation Depending on Traffic Density in Some Landscape Plants. Polish Journal of Environmental Studies, 27.5.

Turkyilmaz A, Sevik H, Isinkaralar K, Cetin M. 2018b. Using Acer platanoides annual Rings to Monitor The Amount of Heavy Metals Accumulated in Air. Environmental monitoring and assessment, 190. 10. 578.

Valladares F, Ninemets U. 2007. The Architecture of Plant Crowns: from Design Rules to Light Capture and Performance. Funct Plant Ecol, 7488. C004. 101.

Yigit N, Cetin M, Ozturk A, Sevik H, Cetin S. 2019. Varitation of Stomatal Characteristics in Broad Leaved Species Based on Habitat. Applied Ecology and Environmental Research 17. 6. pp.12859-12868.

Yigit N, Cetin M, Sevik H, Aricak B. 2018. Variation of Some Micro-Morphological Characters of Leaves of Aesculus hippocastanum Based on Growing Environment. Emergent Life Sciences Research, 4. pp. 45-52.

Yigit N, Sevik H, Cetin M, Gul L. 2016b. Clonal variation in chemical wood characteristics in Hanönü (Kastamonu) Günlüburun black pine (Pinus nigra Arnold. subsp. Pallasiana (Lamb.) Holmboe) seed orchard. Journal of Sustainable Forestry, 35. 7. pp. 515-526.

Yigit N, Sevik H, Cetin M, Kaya N. 2016a. Determination of the effect of drought stress on the seed germination in some plant species. Water stress in plants, pp. 43-62.

Yiğit N, Çetin M, Şevik H. 2018. The Change in Some Leaf Micromorphological Characters of Prunus laurocerasus L. species by Their Habitat. Turkish Journal of AgricultureFood Science and Technology, 6. 11. pp.1517-1521. https://doi.org/10.24925/turjaf.v6i11.1517-1521.1704.

Yucedag C, Ozel HB, Cetin M, Sevik H. 2019. Variability in Morphological Traits of Seedlings From five Euonymus japonicus Cultivars. Environmental Monitoring and Assessment, 191. 5. 285. 